\title{
Pelatihan Peningkatan Kemampuan Bahasa Inggris melalui Media Games di Lingkup Komunitas di KotaTernate
}

\author{
Sulmi Magfirah ${ }^{1}$, Sutisno Adam ${ }^{2}$, Farida Maricar ${ }^{3}$, Indra Purnawan Pandjaitan ${ }^{4}$ \\ sulmi@unkhair.ac.id ${ }^{1}$, sutisno@unkhair.ac.id ${ }^{2}$, faridakandacong@gmail.com³ \\ pindrapurnawan@gmail.com ${ }^{4}$ \\ ${ }_{1,2,3,4}$ Universitas Khairun
}

\begin{abstract}
Article History:
Received: 12-06-2021

Revised : 24-06-2021

Accepted: 23-07-2021
\end{abstract}

\begin{abstract}
The community service activities by Unkhair team in the form of English language skills training in Ternate communities aims to increase the enthusiasm of community members to learn English and improve English skills through effective, creative and fun learning, in this case through media games. The method used prioritizes courage in speaking without worrying about being wrong in pronunciation or expression in using English. The sample are around 40 participants by the community members in Ternate. Games are used as English communication media between mentor and participants. Finally, the result of this activity is the increase of English ability of the participants in using games, therefore the learning process is more effective, creative, and fun.
\end{abstract}

Keywords: Training, media games, creative, effective, fun

\section{Pendahuluan}

Bahasa memiliki peran yang sangat penting dalam kehidupan sehari-hari. Dengan memiliki kemampuan berbahasa yang baik maka seseorang bisa lebih mudah dalam melakukan komunikasi dengan orang lain. Dengan kata lain, penguasaan sebuah bahasa sangatlah penting, terutama bahasa Inggris karena bahasa ini merupakan bahasa internasional, artinya seseorang yang memiliki kemampuan bahasa Inggris yang baik dapat berkomunikasi secara lebih mudah dengan masyarakat internasional. Sesuai dengan salah satu tujuan Tri Dharma Perguruan Tinggi yakni pengabdian kepada masyarakat, maka Universitas Khairun sebagai salah satu lembaga pendidikan tinggi mempunyai tanggung jawab dalam upaya pengembangan kemampuan masyarakat.

Salah satu tujuan dari Pengabdian Kepada Masyarakat ini adalah untuk meningkatkan kemampuan berbahasa Inggris yang dimiliki oleh pihak mitra. Untuk merealisasikan tujuan tersebut para tim dosen Sastra Inggris Universitas Khairun bekerja sama dengan mitra dari komunitas di Ternate yakni Open English Community (OEC) Ternate, untuk melakukan pelatihan Peningkatan berbahasa Inggris dengan media games yang lebih efektif, dan menyenangkan. (Prihantoro, 2018) Materi ajar dalam pembelajaran Bahasa Inggris terfokus pada keterampilan dan keahlian berkomunikasi. Namun, matri keterampilan dan keahlian tidak terpisahkan dari nilai, sikap dan prilaku. Artinya, dalam https://journal.universitasbumigora.ac.id/index.php/ADMA 
aktifitas pembelajaran, empat materi tersebut tetap diajarkan, tetapi fokusnya pada keterampilan dan keahlian berkomunikasi.

Berdasar dari tujuan tersebut, dibutuhkan penguatan kepada mitra setempat berupa soft skill pelatihan berbahasa asing yaitu bahasa Inggris. Untuk mencapai tujuan tersebut, para dosen prodi Sastra Inggris Universitas Khairun melakukan pelatihan berbahasa Inggris melalui kegiatan. (Manurung \& Sambayu, 2017) Berkomunikasi secara lisan dan tulisan dengan menggunakan ragam yang sesuai secara lancar dan akurat yang diwujudkan dalam tiap keterampilan berbahasa melalui listening, spaking, reading dan writing. Sehingga, melalui media edukasi / Games memberikan pengetahuan tambahan kepada para anggota komunitas untuk bisa dimanfaatkan dalam peningkatan kemampuan berbahasa Inggris yang dimiliki oleh pihak mitra, sehingga dapat diimplementasikan dan diterapkan dipercakapan sehari-hari maupun kegiatan formal lainnya.

\section{Metode}

Kegiatan Pengabdian ini bertujuan untuk mengasah skill peserta kegiatan dalam mengaplikasikan kemampuan untuk menyampaikan gagasan ataupun ide sebuah cerita dengan gaya, intonasi, dan alat bantu yang menarik minat audiens ataupun lawan bicara. Sehingga, metode yang digunakan adalah metode media games. Games/Permainan bahasa diidentifikasi sebagai bahasa bermain, dalam artian lain, permaina bahasa bukanlah bahasa buatan secara teknis sebanyak heuristic untuk memodifikasi bahasa, seperti penggunaan kode (Sobhani \& Sadegh Bagheri, 2014). Dalam kegiatan ini, peserta yang telah mendapatkan bekal speaking di bangku perkuliahan, juga mempunyai kemampuan dalam mengaplikasikan materi yang telah diberikan oleh dosen di kelas dengan baik, bagaimana memahami karakter pendengar, mampu mengatur nada dan intonasi serta gesture bersama dengan lawan bicara. Dikatakan berhasil menggunakan basic teknik speaking, jika pendengar mampu menangkap makna dari percakapan yang berlangsung.

Kegiatan ini dilaksanakan pada bulan Desember 2020 dengan melibatkan beberapa dosen program studi sastra inggris, Selama kegiatan berlangsung, peserta aktif mempraktekkan skill Bahasa Inggris yang langsung di mentori oleh mentor dari lulusan Bahasa Inggris dan awardee beasiswa luar negeri. Susunan kegiatan ini dirancang langsung oleh tim PkM Unkhair dengan variasi kegiatan oleh mentor yang ahli di bidangnya. (Azhar Arsyad, 2013) Media pembelajaran dalam proses belajar mengajar dapat mebangkitkan keinginan dan minat yang baru, membangkitkan motivasi dan rangsangan kegiatan belajar bahkan membawa pengaruh-pengaruh psikologis terhadap sis atau peserta pelatihan. 
Setelah mentor memberikan instruksi kepada peserta tentang langkah-langkah pelaksanaan kegiatan. Salah satu metode menarik dan menyenangkan dalam pembelajaran adalah menggunakan game, pembelajaran berbasis permainan telah menjadi tren yang berkembang kuat di abad 21, (Al Irsyadi et al., 2019). Sehingga, dalam kegiatan ini peserta kemudian diarahkan dan dibagi menjadi beberapa tim berdasarkan kelompok masingmasing, untuk kemudian di praktekkan secara langsung dengan menggunakan full Bahasa Inggris selama tiga sesi permainan yang menghibur sekaligus mengedukasi sesuai dengan tema kegiatan yang berlangsung selama 5 jam dan berlokasi di Kebun Cengkeh, kelurahan Gambesi. Selanjutnya, setiap sesi kegiatan terdapat beberapa tim dosen yang bertugas untuk menilai tim mana yang berhak memenangkan setiap sesi permainan tersebut, sekaligus sebagai bentuk evaluasi kegiatan Evaluasi kegiatan ini juga bertujuan untuk memperbaiki kekurangan yang selanjutnya diaplikasikan dalam kegiatan serupa sebagai bentuk tridharma perguruan tinggi oleh tim PkM Prodi Sastra Inggris Unkhair selanjutnya.

\section{1) Khalayak Sasaran}

Dengan diselenggarakannya kegiatan PkM ini, tim dosen Sastra Inggris Universitas Khairun berharap dapat lebih secara aktif membantu meningkatkan kemampuan berbahasa Inggris terhadap Komunitas-komunitas penggiat bahasa asing khususnya bahasa Inggris di Kota Ternate maupun se Maluku Utara. Dalam meningkatkan kemampuan berbahasa Inggris pada akhirnya menambah kecakapan dan percaya diri kepada anggota komunitas untuk selalu menggunakan Bahasa Inggris dalam kegiatan komunitas maupun kegiatan sehari-hari. Dengan begitu skill berbahasa Inggris mereka akan meningkat dan lebih percaya diri dalam berbahasa Inggris.

\section{2) Rangkaian Kegiatan}

Rangkaian kegiatan yang disusun oleh tim unkhair dalam memecahkan masalah di atas melalui tahapan sebagai berikut : 


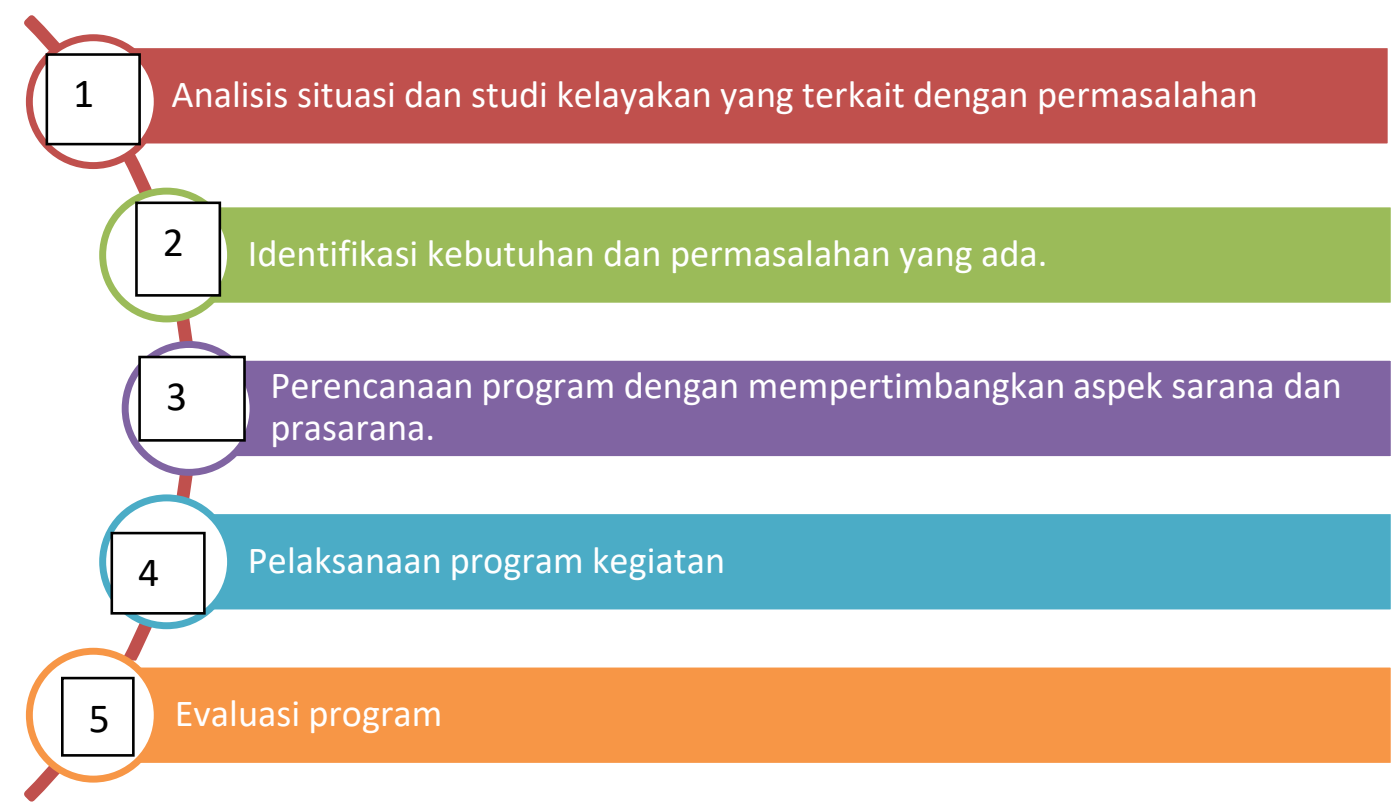

Gambar 1. Rangkaian kegiatan pengabdian kepada masyarakat

\section{3) Rancangan Evaluasi}

Evaluasi dilaksanakan sejak tahap persiapan yaitu pemilihan khalayak sasaran serta materi pelatihan sampai dengan pelaksanaan kegiatan dan pelaporan hasil akhir dalam bentuk wawancara pengalaman anggota komunitas setelah mengikuti kegiatan.

\section{4) Jadwal Kegiatan}

Kegiatan Pelatihan Peningkatan Kemampuan berbahasa Inggris bagi Open English Community (OEC) Ternate dimulai dari tahap persiapan meliputi analisis situasi, permasalahan kemudian pelaksanaan, dan evaluasi. Pelaksanaan pelatihan direncanakan pada tanggal bulan Desember 2020 di Kebun Cengkeh Gambesi Ternate Selatan.

Tabel 1 : Susunan jadwal pelaksanaan kegiatan

\begin{tabular}{|c|c|c|c|c|}
\hline \multirow{3}{*}{ No } & \multirow{3}{*}{$\begin{array}{l}\text { Jenis } \\
\text { Kegiatan }\end{array}$} & \multicolumn{3}{|c|}{ Desember 2020} \\
\hline & & \multicolumn{3}{|c|}{ Minggu Ke } \\
\hline & & II & III & IV \\
\hline 1 & Survey Lokasi & & & \\
\hline 2 & $\begin{array}{l}\text { Persiapan } \\
\text { Kegiatan }\end{array}$ & & & \\
\hline 3 & Pelaksanaan & & & \\
\hline 4 & Evaluasi & & & \\
\hline
\end{tabular}




\section{Pembahasan}

\section{1) Mekanisme Pelaksanaan Kegiatan}

Langkah pertama yang kami lakukan dalam kegiatan ini adalah dengan mengadakan survey lokasi yang akan diguanakan untuk kegiatan PkM. Hal ini untuk mengetahui kondisi yang sebenarnya dan sesuai dengan yang dibutuhkan dalam kegiatan ini. Kegiatan pendekatan ini dilakukan kurang lebih selama satu minggu. Adapun yang dilakukan adalah mengunjungi tempat-tempat yang sesuai dengan kapasitas mahasiswa sehingga pelaksanaan kegiatan akan berjalan lancar dan sesuai dengan rencana awal.

Setelah mendapatkan tempat untuk melakukan kegiatan ini, yaitu kebun cengkeh di kelurahan Gambesi, tim prodi sastra Inggris Unkhair kemudian melakukan persiapan run down kegiatan beserta mentor seperti menyiapkan jenis kegiatan untuk dilakukan oleh peserta dan kesiapan komunitas Bahasa Inggris yang sesuai dengan topik kegiatan.

Selanjutnya, dilakukan briefing sehari sebelum oleh para participants yang akan melakukan kegiatan ini. Dan pada hari berikutnya, pelaksanaan kegiatan. Setelah pementasan, kemudian dilakukan evaluasi kegiatan. Evaluasi ini bertujuan untuk mengetahui kendala selama berlangsungnya kegiatan yang dilakukan oleh dosen yang bersangkutan. Serta untuk menjadi pembelajaran lanjutan untuk kegiatan program Sastra Inggris selanjutnya.

\section{2) Model Kegiatan}

Kegiatan dibagi menjadi 3 bagian yaitu individu, group 2, dan group 3. Dalam kegiatan individu ini, peserta diarahkan untuk getting to know / find someone who dengan durasi kegiatan 15 menit. Kegiatan ini bertujuan untuk melatih confidence peserta untuk bertanya dan menjawab pertanyaan kepada lawan bicara. Terdapat 16 kotak clues untuk digunakan, setelah bertanya kemudian wajib menulis nama responden, mahasiswa yang telah menyelesaikan 4 kotak horizontal/vertical/diagonal melaporkan kepada mentor dan "Bingo". Detail kegiatan Bingo dapat dilihat pada Tabel 2.

Tabel 2. Kegiatan Bingo

\begin{tabular}{|c|c|c|c|}
\hline \multicolumn{4}{|c|}{ Find Someone Who.... } \\
\hline Is an only child & $\begin{array}{l}\text { Has a sports } \\
\text { trophy }\end{array}$ & Was born in Ternate & Is a vegetarian \\
\hline Doesn't like chocolate & Can cook & Is afraid of heights & $\begin{array}{l}\text { Has } 2 \text { or more } \\
\text { brothers }\end{array}$ \\
\hline Likes online shop & $\begin{array}{l}\text { Has } 2 \text { or more } \\
\text { sisters }\end{array}$ & Went to theater & Hates snake \\
\hline Has 2 pets & $\begin{array}{l}\text { Likes to play } \\
\text { tiktok }\end{array}$ & Favorite color is green & $\begin{array}{l}\text { Has a birthday } \\
\text { this month }\end{array}$ \\
\hline
\end{tabular}


Pada model kegiatan group 2, terdapat dua jenis kegiatan di bagian ini yakni; quiz dan scavenger hunt. Kegiatan pertama yang mengasah kekompakan team adalah scavenger hunt, kegiatan ini berdurasi 30 menit dengan tetap mematuhi protocol kesehatan. Terdapat 20 clues untuk setiap tim pecahkan dan sekaligus bertujuan untuk membangun kreatifitas dari tiap tim karena setiap clues membutuhkan kesepakatan dan kekompakan tim sehingga memperoleh poin oleh mentor kegiatan. Kemudian, tim yang menyelesaikan semua clues dengan cepat adalah pemenangnya. Berikut adalah bentuk Scavenger Hunt yang dapat dilihat pada gambar 2 .

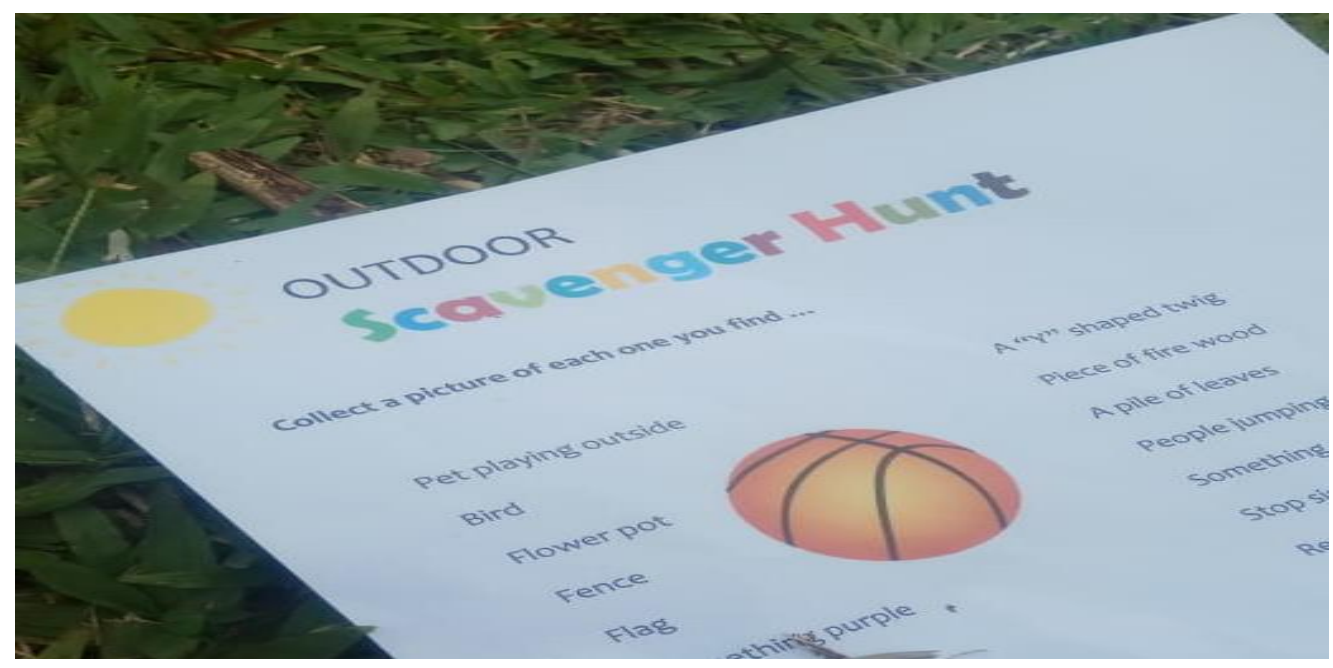

Gambar 2. Bentuk Scavenger Hunt

Selanjutnya, kegiatan kedua yang juga mengasah kekompakan kelompok dan ketepatan dalam menjawab setiap pertanyaan oleh panitia dan mentor, jenis kegiatan pertanyaan rebutan dengan durasi 30 menit. Setiap tim kemudian menempati posisi yang telah di tetapkan oleh panitia kegiatan. Sebelum memulai kegiatan, setiap tim menampilkan yelyel untuk memeriahkan kegiatan terakhir. Terdapat 30 pertanyaan random yang telah disipakan oleh mentor dan setiap tim berlomba untuk memecahkan jawaban dari setiap pertanyaan yang dilontarkan oleh mentor. List pertanyaan dapat dilihat pada gambar 3.

RUIZ PRAKTIKUM

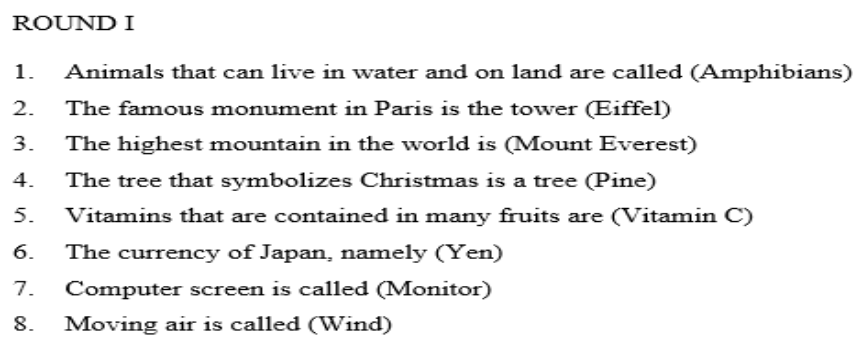

Gambar 3. List pertanyaan 


\section{3) Hasil Kegiatan}

Berdasarkan hasil evaluasi kegiatan setelah menjalani pelatihan, terlihat adanya peningkatan hasil belajar peserta kegiatan, melalui antusias peserta kegiatan dalam mengikuti seluruh rangkaian pelatihan. Sebelum mengikuti pelatihan para peserta umumnya menganggap bahasa Inggris merupakan bahasa asing yang sangat sulit dipelajari, namun setelah mengikuti pelatihan dengan menggunakan metode games mulai mengalami kemudahan dan antusias untuk melakukan kegiatan dengan topik yang berbeda karena pelatihana yang terasa menyenangkan, selain itu kegiatan ini merupakan kegiatan pertama yang dilakukan di Fakultas IImu Budaya khususnya di Program Studi Sastra Inggris.

Peserta selama kegiatan berlangsung terlihat antusias dan termotivasi melaksanakan permainan bersama dengan kelompok masing-masing. Karena, selain kegiatan ini terasa seperti hiburan akan tetapi secara tidak langsung peserta mengasah jumlah vocabulary yang mereka kuasai dan menambah kosa kata baru selama proses tersebut, dan juga melatih leadership tentang bagaimana memulai percakapan dengan teman baru, bagaimana merespon lawan bicara dan bagaimana membuat kegiatan tersebut terasa menyenangkan.

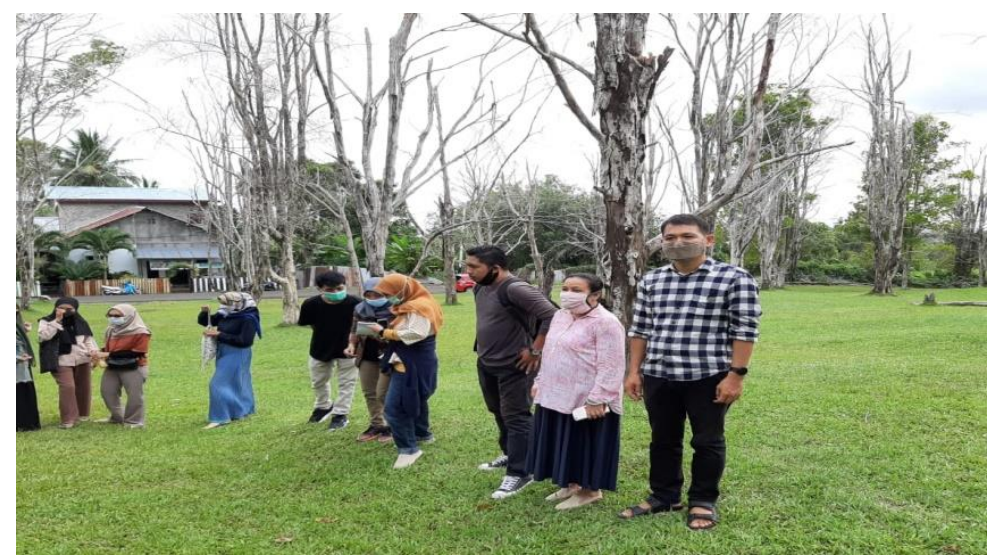

Gambar 4 : Tim memberikan arahan kegiatan pengabdian kepada masyarakat
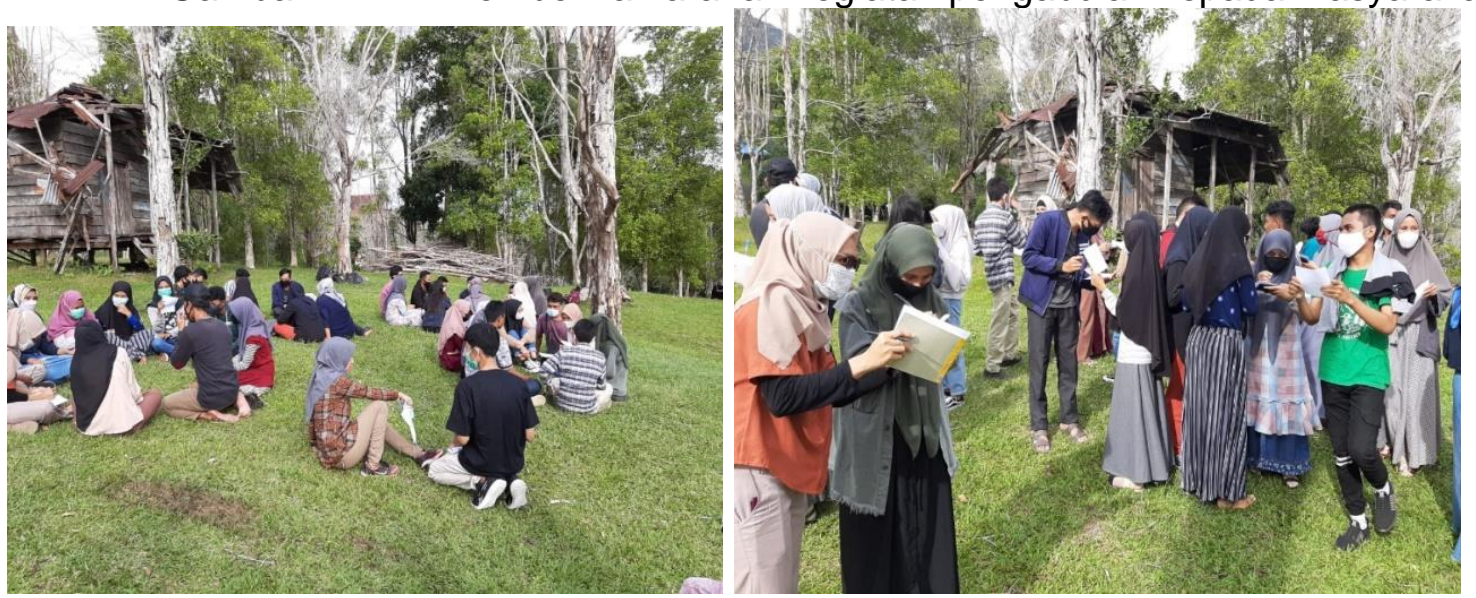

Gambar 5: Foto-foto dokumentasi Kegiatan Pelatihan Kemampuan Bahasa Inggris Melalui Media Games di Kota Ternate 


\section{Kesimpulan}

Pembelajaran dengan media games dapat meningkatkan kemampuan dalam berbahasa Inggris. Kegiatan pelatihan ini memberikan dampak positif bagi para anggota komunitas. Para peserta atau anggota komunitas yang sudah mendapatkan pelatihan dalam program pengabdian ini dapat menerapkan secara langsung kepada teman yang lainnya dalam lingkup komunitas maupun di luar lingkup komunitas.

\section{Ucapan Terimakasih}

Penulis mengucapkan terima kasih kepada Program Studi Sastra Inggris Fakultas IImu Budaya Universitas Khairun serta mitra yang terlibat dalam kegiatan ini yaitu Tim OEC (Open English Community) di Kota Ternate sehingga pelaksanaan pengabdian kepada masyarakat ini dapat berjalan dengan baik. Meskipun situasi dan kondisi pandemic saat ini, akan tetapi kegiatan pelatihan ini tetap berjalan sesuai rencana serta peserta antusias selama kegiatan berlangsung sampai dengan kegiatan berakhir.

\section{Daftar Pustaka}

Al Irsyadi, F. Y., Annas, R., \& Kurniawan, Y. I. (2019). Game Edukasi Pembelajaran Bahasa Inggris untuk Pengenalan Benda-Benda di Rumah bagi Siswa Kelas 4 Sekolah Dasar. Jurnal Teknologi Dan Informasi, 9(2), 78-92. https://doi.org/10.34010/jati.v9i2.1844

Azhar Arsyad. (2013). Metode Pembelajaran. Raja Grafindo Persada.

Manurung, P., \& Sambayu, H. (2017). Meningkatkan Kemampuan Bahasa Inggris Mahasiswa/i Program Studi Pendidikan Bahasa Inggris Fkip-Una dengan Literature Aprroach. 1080-1092. https://doi.org/10.31227/osf.io/a29r4

Prihantoro, A. (2018). Mengembangkan Strategi Pembelajaran Bahasa Inggris Yang Kreatif. Ulumuddin: Jurnal IImu-IImu Keislaman, 8(1), 49-62. https://doi.org/10.47200/ulumuddin.v8i1.173

Sobhani, M., \& Sadegh Bagheri, M. (2014). Attitudes toward the effectiveness of communicative and educational language games and fun activities in teaching and learning English. Theory and Practice in Language Studies, 4(5), 1066-1073. https://doi.org/10.4304/tpls.4.5.1066-1073 